\title{
Melanophylla dianeae (Torricelliaceae), a New, Critically Endangered Species from a Remnant Forest Fragment in East-central Madagascar
}

\author{
Porter P. Lowry II
}

Missouri Botanical Garden, 4344 Shaw Blvd., St. Louis, Missouri 63110, U.S.A.; Institut de Systématique, Évolution, et Biodiversité (ISYEB), Unité Mixte de Recherche 7205, Centre National de la Recherche Scientifique/Muséum National d'Histoire Naturelle/École Pratique des Hautes Études, Université Pierre et Marie Curie, Sorbonne Universités, C.P. 39, 57 rue Cuvier, F-75005 Paris, France.

pete.lowry@mobot.org

Chris Birkinshaw

Missouri Botanical Garden, Madagascar Research and Conservation Program, B.P. 3391, Antananarivo 101, Madagascar.

George E. Schatz

Missouri Botanical Garden, 4344 Shaw Blvd., St. Louis, Missouri 63110, U.S.A.

Patrice Antilahimena

Missouri Botanical Garden, Madagascar Research and Conservation Program, B.P. 3391, Antananarivo 101, Madagascar.

Abstract. Melanophylla dianeae Lowry \& G. E. Schatz (Torricelliaceae) is described as a new species from a remnant fragment of highly threatened humid forest in east-central Madagascar. Collected for the first time in 2016, just five adult trees are known from an area that has been heavily impacted by forest clearing for slash-and-burn agriculture. Mature fruits have been collected in an attempt to grow seedlings, and airlayering is being trialed on an adult tree to produce vegetative material for propagation, as part of an effort to ensure ex situ conservation of this rare species. An IUCN Red List risk of extinction assessment reveals that $M$. dianeae is Critically Endangered.

Key words: Conservation, IUCN Red List, Madagascar, Melanophylla, new species, Torricelliaceae.

Between 2016 and 2019, extensive fieldwork was conducted in a small area situated around the Betampona Special Reserve, within Atsinanana Region in east-central Madagascar, as part of a project funded by the Darwin Initiative. The aim of this project was to document 500 plant species growing in remnant, highly threatened forest fragments in the Ivoloina and Ifontsy River valleys and to conserve them though ex situ interventions (Madagascar Fauna and Flora Group, 2019). Before human colonization, the landscape in this area is thought to have been covered by humid evergreen forest. However, with the exception of the Betampona Reserve, nearly all of the area's original vegetation has been cleared, mainly due to the expansion of slash-and-burn agriculture, primarily to grow hill rice. The few small fragments that remain are disappearing rapidly and will very likely be lost in the near future. During the first 18 months of the project, a team of five Malagasy field botanists, Patrice Antilahimena, Benjamina Rajaijaona, Arsene Giovanni Rakotonirina, Maheninsoa Harisandy Rasoanindriana, and Remi Anthony Syde, collected vouchered seed samples from these forest fragments, which were propagated at the nearby Ivoloina Parc for conservation as living plants and/or dispatched to the Silo National des Graines Forestières (SNGF), Madagascar's national seed bank, located in Antananarivo. During this three-year project, which ended in March 2019, a total of 953 vouchered samples were collected, representing an estimated 500 species.

One of the species collected as part of this project was a highly distinctive member of the Malagasy endemic genus Melanophylla Baker. Until recently, Melanophylla was usually placed in Cornaceae (Harms, 1897; Keraudren, 1958), Montiniaceae (Thorne, 2000), or its own family, Melanophyllaceae (Cronquist, 1988; Takhtajan, 1997; Schatz et al., 1998). Recent evidence from molecular phylogenetic analyses has led to its inclusion in Torricelliaceae, along with two other genera: Aralidium Miq. from the Malay Peninsula and western Malesia, and Torricellia DC. from the Himalayas and southwestern China (Chandler \& Plunkett, 


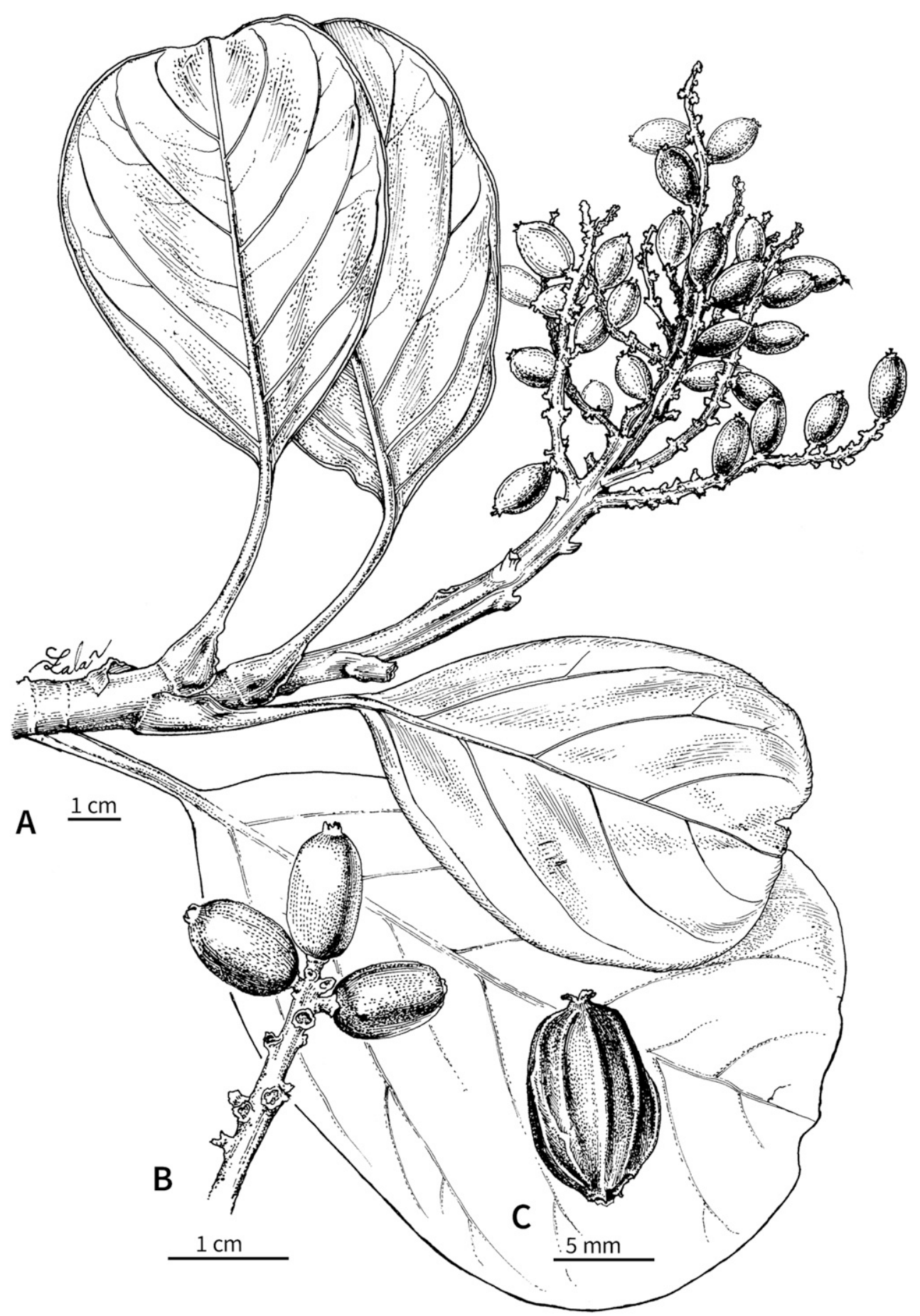

Figure 1. Illustration of Melanophylla dianeae Lowry \& G. E. Schatz. - A. Fruiting branch. - B. Secondary axis of infructescence. - C. Dry fruit. Based on Antilahimena et al. 9521 (TAN). Drawn by Roger Lala Andriamiarisoa.

2004; Plunkett et al., 2004, 2018). A taxonomic revision of Melanophylla was published by Schatz et al. (1998), who recognized six species, to which a seventh species was added several years later by McPherson and
Rabenantoandro (2002). Careful comparison of the collections made in the forest fragments near the Betampona Reserve with material of the seven currently recognized species (Madagascar Catalogue, 2019) reveals 


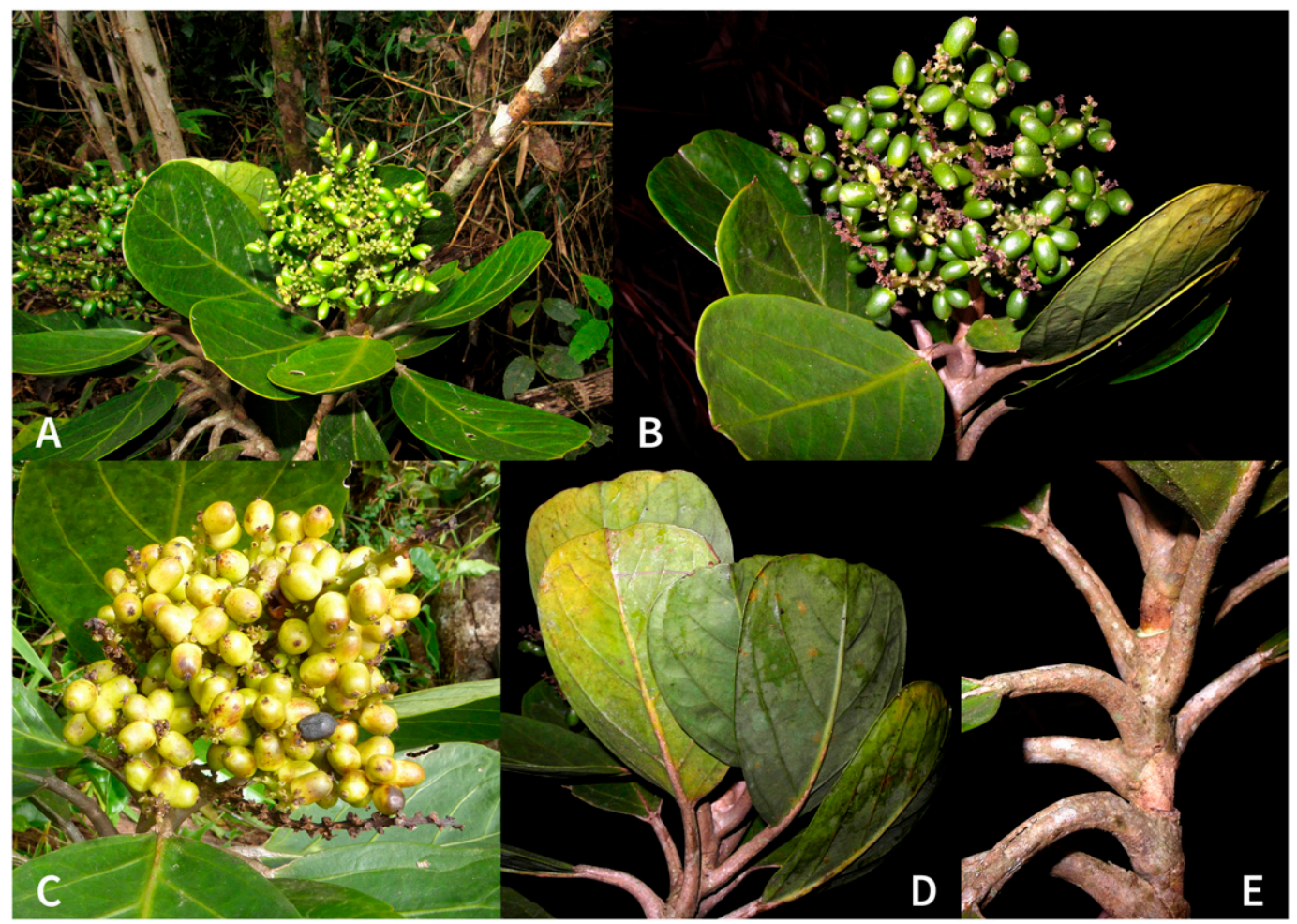

Figure 2. Photographs of Melanophylla dianeae Lowry \& G. E. Schatz. —A. Branch with two young infructescences. -B. Immature fruit. - C. Mature fruit. - D. Leaves (abaxial surface) showing shape of blade and number of secondary veins. -E. Detail of petioles. A, B, D, E from Syde 21; C from Antilahimena 9521. Photographs by P. Antilahimena (A, B, E, F) and C. Birkinshaw (D).

that they clearly represent a distinctive new species, which we describe here.

Melanophylla dianeae Lowry \& G. E. Schatz, sp. nov. TYPE: Madagascar. Atsinanana Region [Toamasina], Distr. Toamasina II, commune rurale Sahambala, fokontany Sahavongo, village le plus proche Sahavongo, lambeau de forêt Vohimihambagna, forêt dense humide de basse altitude, $18^{\circ} 01^{\prime} 37^{\prime \prime} \mathrm{S}$, $49^{\circ} 06^{\prime} 48^{\prime \prime} \mathrm{E}, 757 \mathrm{~m}, 10$ Dec. 2016, young fr., Syde 21 (holotype, MO-6911400!; isotypes, K!, MO-6911401!, $\mathrm{P}$ [P00722701]!, TAN!).

Diagnosis. Melanophylla dianeae Lowry \& G. E. Schatz resembles $M$. madagascariensis Keraudren and $M$. perrieri Keraudren in having coriaceous leaves, but differs in having smaller leaves (lamina 7-14 $\times 5-8 \mathrm{~cm}$ vs. [22-]28-33 $\times 8$ $20 \mathrm{~cm}$ in M. madagascariensis and $22-33 \times 7.5-18.5 \mathrm{~cm}$ in $M$. perrieri) with a truncate to slightly rounded apex (vs. rounded) and only 4 or 5 secondary veins per side (vs. 7 or 8 in M. madagascariensis and 12 to 18 in M. perrieri), as well as a shorter petiole (4.5-5.5 cm vs. [5-]7-11 cm in M. madagascariensis and 5-8.5 $\mathrm{cm}$ in M. perrieri).

Sparsely branched tree to $17 \mathrm{~m}$ tall, $30 \mathrm{~cm} \mathrm{DBH}$; twigs 7-8 mm diam., glabrous. Leaves clustered toward apex of twigs; lamina obovate to nearly obtriangular,
7-14 $\times 5-8 \mathrm{~cm}$, glabrous, succulent in vivo, coriaceous in sicco, adaxial surface slightly concave; base cuneate, symmetrical; margin entire, slightly revolute, sometimes with a few broad, shallow crenulations toward apex; apex truncate to slightly rounded; venation obscurely brochidodromous, with 4 or 5 pairs of slightly curved secondary veins, higher order venation obscure, midrib slightly raised above, conspicuously raised beneath, ca. 2-3 mm wide at base; both surfaces glabrous, in vivo green above, venation yellow-green, lamina yellowgreen beneath, venation green, in sicco olive green to khaki above, dark brown beneath; petiole (2.5-) 4.5-5.5 cm long, 3-6 $\mathrm{mm}$ in diam. at base, tan in vivo, deeply channeled, winged along entire length, margins strongly inrolled, base strongly sheathing, amplexicaul, 7-10 $\mathrm{mm}$ broad. Inflorescences terminal, erect, branched, irregularly globose to obconical panicles, primary axis $12-17 \mathrm{~cm}$, secondary axes ca. 25 , proximal one inserted $3-4 \mathrm{~cm}$ from base, $8-10.5 \mathrm{~cm}$, progressively shorter distally, shortest ca. $2 \mathrm{~cm}$, flowers/ fruits borne racemosely along length of secondary axes, each subtended by a bract; bracts ovate-triangular, $1-1.8 \times 1-2 \mathrm{~mm}$, minutely ciliate; pedicels $1-1.5 \mathrm{~mm}$, bearing at apex a bilobed involucel comprising 2 united 


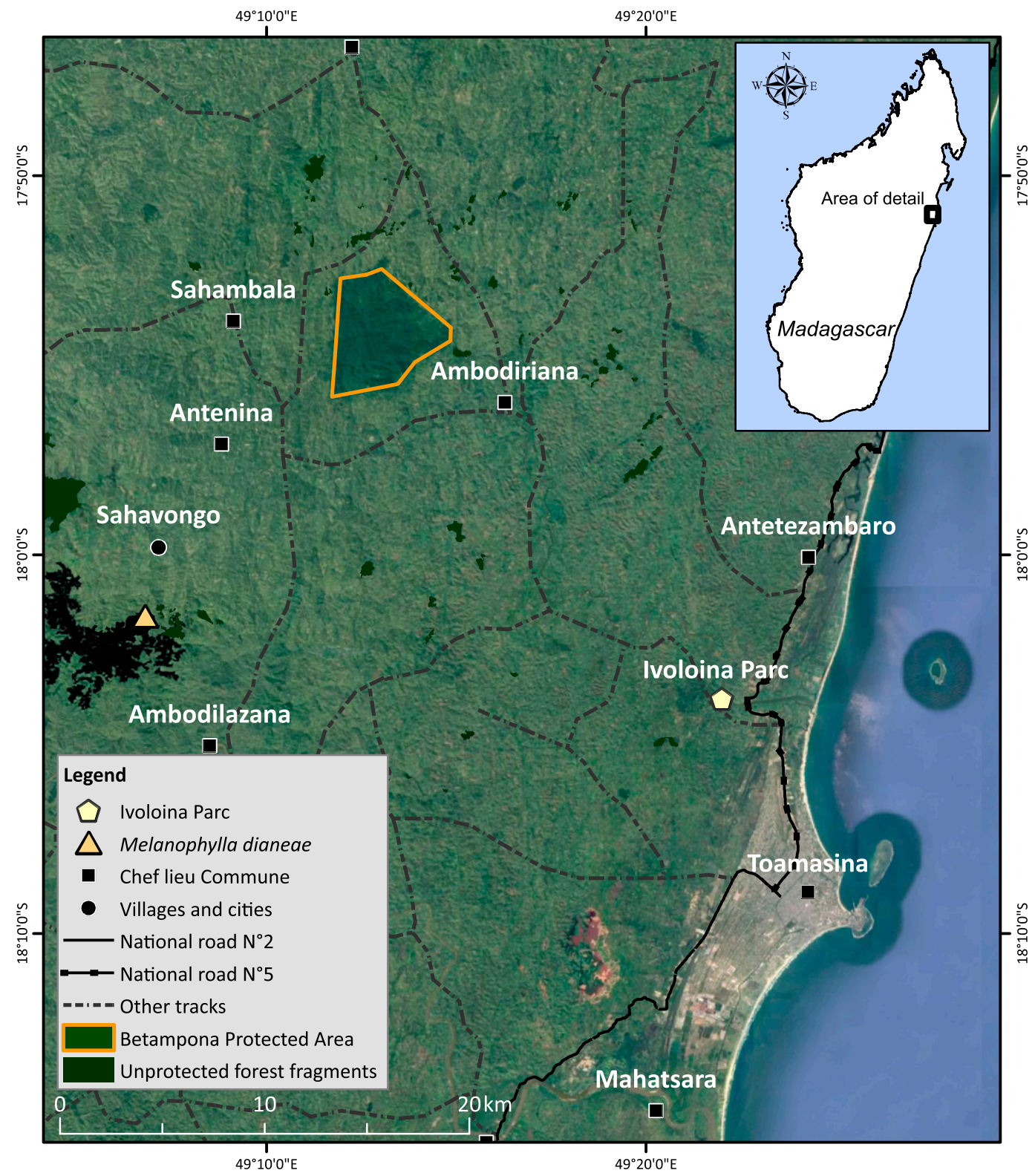

Figure 3. Geographic distribution of Melanophylla dianeae Lowry \& G. E. Schatz in east-central Madagascar. Map prepared by Fano Rajaonary.

bracteoles, $1.5 \mathrm{~mm}$ across, pale green in vivo, minutely ciliate. Flowers not seen. Fruit a fleshy drupe, ellipsoid to slightly ovoid, $7-9 \times 3.5-5 \mathrm{~mm}$, yellow-green to green when young, greenish yellow at maturity, shiny, persistent calyx a low, irregularly lobed, pale green collar ca. $0.5 \mathrm{~mm}$ high; styles 3 , initially persistent, ca. 1.5-1.8 mm, drying and falling off. Figures 1, 2 .

Distribution and habitat. Melanophylla dianeae is known from the eastern part of a much fragmented and degraded band of dense, humid forest that follows the southern watershed of the Ivoloina River valley, near the village of Sahavongo (Fig. 3). The population is located ca. $14 \mathrm{~km}$ southwest of the southern boundary of the Betampona Special Reserve (Fig. 4). Melanophylla dianeae was not observed in the more westerly parts of this forest band or in any of the ca. 15 other forest fragments within the Ivoloina River valley that were visited as part of the Darwin Initiative project.

IUCN Red List criteria. During two days of searching conducted by the Darwin Initiative project field 

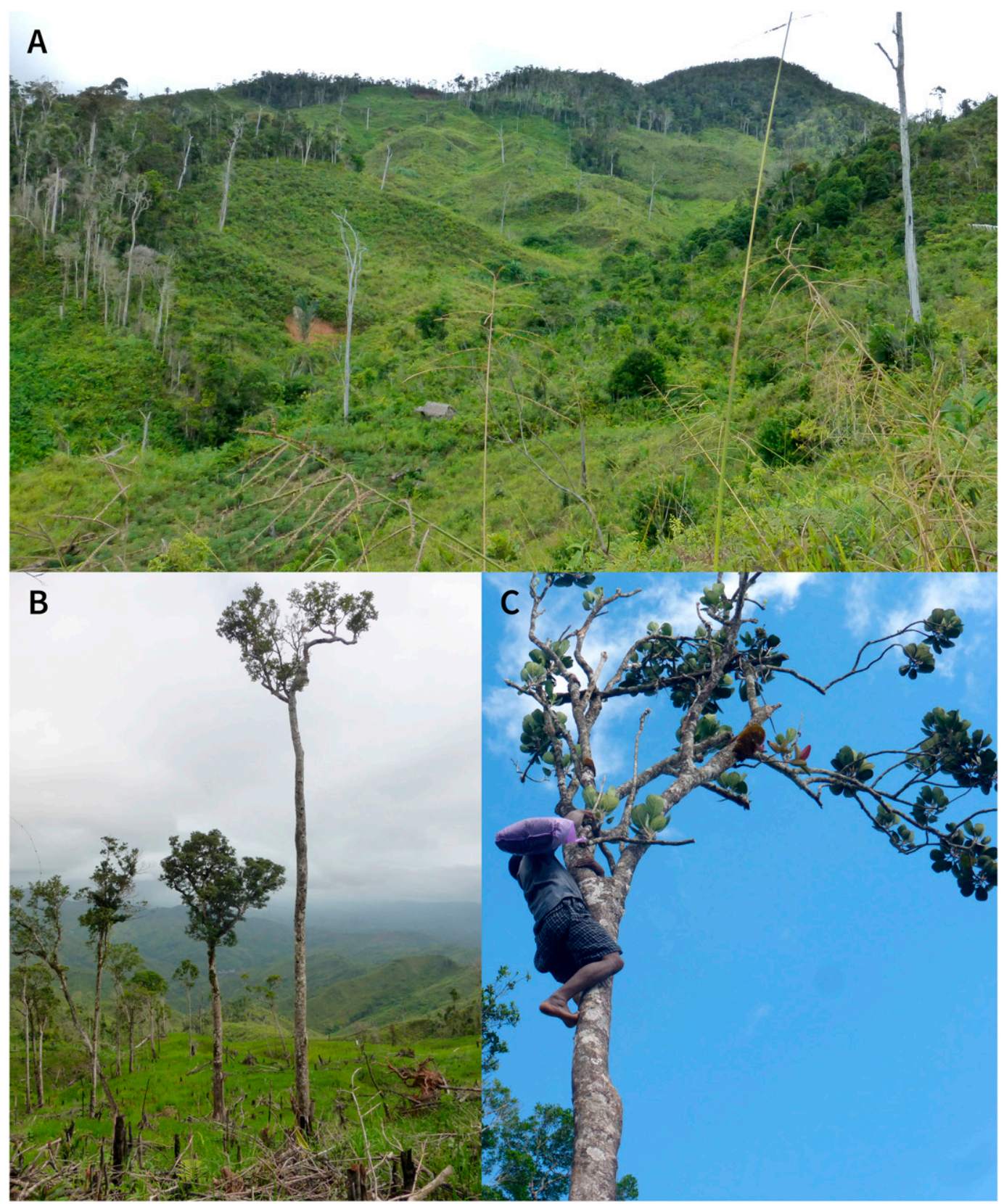

Figure 4. Habitat of Melanophylla dianeae Lowry \& G. E. Schatz. - A. Remnant forest fragment being cleared to cultivate hill rice. - B. Degraded habitat in area where the type material was collected. —C. Horticulturalists from Ivoloina Parc climbing tree to set up air-layering to provide vegetatively propagated material for ex situ cultivation. Photographs by C. Birkinshaw.

team in the vicinity of the plant initially located in 2016, a total of five mature individuals of Melanophylla dianeae were located. In addition, an uncounted number of immature individuals were noted in the vicinity of these plants. The most widely separated individuals were ca. $1 \mathrm{~km}$ apart from one another. The forest occupied by these plants is unprotected, fragmented by ongoing shifting cultivation, and degraded by uncontrolled timber exploitation. In February 2019, a sample of seeds was collected from the originally located tree (from which the type material was gathered) and sown at Ivoloina Parc, but to date none of them have germinated. Attempts are now being made to propagate $M$. dianeae by air-layering. With regard to its risk of 
Table 1. Comparison of diagnostic characters among Melanophylla dianeae Lowry \& G. E. Schatz, M. madagascariensis Keraudren, and M. perrieri Keraudren.

\begin{tabular}{|c|c|c|c|}
\hline Characters & M. dianeae & M. madagascariensis & M. perrieri \\
\hline \multicolumn{4}{|l|}{ Leaf blade: } \\
\hline Shape & obovate to nearly obtriangular & obovate to narrowly obovate & obovate \\
\hline Apex & truncate to slightly rounded & rounded & rounded \\
\hline Margin & $\begin{array}{l}\text { entire with a few broad, shallow } \\
\text { crenulations }\end{array}$ & crenate & weakly crenate distally \\
\hline Size & $7-14 \times 5-8 \mathrm{~cm}$ & $(22-) 28-33 \times 8-20 \mathrm{~cm}$ & $22-33 \times 7.5-18.5 \mathrm{~cm}$ \\
\hline Secondary veins (per side) & 4 or 5 & 7 or 8 & 12 to 18 \\
\hline Petiole length & $4.5-5.5 \mathrm{~cm}$ & $(5-) 7-11 \mathrm{~cm}$ & $5-8.5 \mathrm{~cm}$ \\
\hline
\end{tabular}

extinction according to the IUCN Red List Categories and Criteria (IUCN, 2012), M. dianeae exhibits a geographic range in the form of an extent of occurrence and area of occupancy of $<1 \mathrm{~km}^{2}$, and exists at a single location with respect to the principal threat of forest clearing for shifting agriculture; it can therefore be assessed as Critically Endangered [CR Blab(i,ii,iii,iv,v)+ 2ab(i,ii,iii,iv,v); D].

Etymology. We are delighted to name this remarkable new species in honor of Diane Wyse Jackson, whose tireless efforts over the last nine years have contributed tremendously to the success of the Missouri Botanical Garden and have inspired and encouraged those of us involved in the Garden's Madagascar Program. Diane has visited Madagascar twice since coming to the Garden, traveling to the east-central part of the island on both occasions.

Vernacular name. Nofonakoho beravina (Betsimisaraka dialect) (Syde 21).

Notes. In the identification key to species of $\mathrm{Mel}$ anophylla provided by Schatz et al. (1998) in their revision of the genus, $M$. dianeae would key out under lead 2, with species having thick coriaceous leaf blades (M. madagascariensis Keraudren and M. perrieri Keraudren). Our new species can be readily distinguished from these two taxa by its smaller leaves with fewer secondary veins, along with several other foliar features, as summarized in Table 1. A scanned image of the holotype is available through the Madagascar Catalogue (2019).

Paratype. MADAGASCAR. Atsinanana [Toamasina]: Distr. Toamasina II, commune rurale Sahambala, fokontany Sahavongo, village de Sahavongo, $18^{\circ} 01^{\prime} 37^{\prime \prime} \mathrm{S}, 49^{\circ} 06^{\prime} 48^{\prime \prime} \mathrm{E}$, 764 m, 10 Feb. 2019, fr., Antilahimena et al. 9521 (MO, P, TAN).

Acknowledgments. The fieldwork conducted in the forest fragments near the Betampona Reserve that led to the discovery of Melanophylla dianeae was supported by a generous grant from the U.K. Government's Darwin Initiative. We thank Roger Lala Andriamiarisoa for the excellent illustration, Fano Rajaonary for preparing the distribution map, and two anonymous reviewers for helpful suggestions. We gratefully acknowledge courtesies extended by the government of Madagascar (Ministère de l'Environnement et Développement Durable, permit no. 30218/MEEF/SG/DGF/DSAP/SCB.Re).

\section{Literature Cited}

Chandler, G. T. \& G. M. Plunkett. 2004. Evolution in Apiales: Nuclear and chloroplast markers in (almost) perfect harmony. Bot. J. Linn. Soc. 144: 123-147.

Cronquist, A. 1988. The Evolution and Classification of Flowering Plants. Columbia University Press, New York.

Harms, H. 1897. Cornaceae. Pp. 250-270 in H. G. A. Engler \& K. Prantl (editors), Die natürlichen Pflanzenfamilien III, Vol. 8. Engelmann, Leipzig.

IUCN. 2012. IUCN Red List Categories and Criteria, Version 3.1. Second edition. Prepared by the IUCN Species Survival Commission. IUCN, Gland, Switzerland; Cambridge, United Kingdom.

Keraudren, M. 1958. Cornacées. Fl. Madagasc. 158: 1-17.

Madagascar Catalogue. 2019. Catalogue of the plants of Madagascar. Missouri Botanical Garden, St. Louis and Antananarivo. <http://www.tropicos.org/Project/Madagascar>, accessed 12 September 2019.

Madagascar Fauna and Flora Group. 2019. The Darwin Initiative. <https://www.madagascarfaunaflora.org/darwininitiative.html>, accessed 12 September 2019.

McPherson, G. \& J. Rabenantoandro. 2002. Melanophylla angustior (Melanophyllaceae), a new species from southeastern Madagascar. Adansonia, sér. 3, 24: 263-265.

Plunkett, G. M., G. T. Chandler, P. P. Lowry II, S. M. Pinney \& T. S. Sprenkle. 2004. Recent advances in understanding Apiales and a revised classification. S. African J. Bot. 70: 371-381.

Plunkett, G. M., Q.-Y. Xiang, P. P. Lowry II \& G. E. Schatz. 2018 [2019]. Torricelliaceae. Pp. 549-556 in J. W. Kadereit $\&$ V. Bittrich (editors), The Families and Genera of Vascular Plants. Springer-Verlag, Berlin.

Schatz, G. E., P. P. Lowry II \& A.-E. Wolf. 1998. Endemic families of Madagascar. I. A synoptic revision of Melanophylla Baker (Melanophyllaceae). Adansonia, sér. 3, 20: 233-242.

Takhtajan, A. 1997. Diversity and Classification of Flowering Plants. Columbia University Press, New York.

Thorne, R. F. 2000. The classification and geography of the flowering plants. Bot. Rev. 66: 441-647. 